\title{
POLA HUBUNGAN RELASIONAL PADA PASANGAN SEJENIS (SEBUAH PENELITIAN EMPIRIS DENGAN PERSPEKTIF TEORI DIALEKTIKA RELASIONAL)
}

\author{
MOCH. NASHRULLOH \\ Pascasarjana KPI Universitas Islam Negeri (UIN) Sunan Ampel Surabaya \\ Email : nazrul.arief@gmail.com
}

\begin{abstract}
:
This paper try to describe about the system of relational connection in the guy couple. This connection analyzed by it's theory to get a conclusion. Actually, in the relational connection, there are the dialectic of centriphetal and centrifugal in which centriphetal energy pull inside to the center of connection. It's diffirent from centrifugal energy that pull outside from the center of connection. Both of that energy dominate connection one to the other. Because of that, the principle duty of each couple is harmonize both of the diffirent energy for balance, but not make disappear centrifugal energy. Certainly, destructive energy of centrifugal is not avoided. That energy is not be passed away, but it's has to be compromised and communicated well, so it's relation can be composed powerfully.
\end{abstract}

Keywords : dialectics, dialogue, centripetal, centrifugal, relational.

\section{PENDAHULUAN}

Manusia pada dasarnya merupakan makhluk sosial yang tidak bisa hidup sendiri dan tidak bisa lepas dari kebutuhan akan pasangan hidup. Karena itu, secara naluriah manusia selalu berusaha untuk mencari pasangan hidupnya guna melengkapi kebahagiaan dirinya. Baginya, kebahagiaan hidup tersebut akan lebih bermakna jika ada pasangan yang ada di sampingnya.

Sebagai ciptaan Tuhan, ternyata sejak lahir manusia telah dianugerahi oleh sang pencipta berupa orientasi seksual yang berbeda-beda. Orientasi seksual tersebut berpengaruh bagi setiap individu dalam mengidentifikasi dirinya apakah termasuk kategori heteroseksual, homoseksual, ataukah biseksual. Karena ketiga orientasi seksual inilah yang menentukan seseorang tertarik untuk berhubungan biologis dengan laki-laki ataukah perempuan.

Akhir-akhir ini, persoalan orientasi seksual sedang menjadi sorotan bersama di tanah air, utamanya yang menyangkut persoalan Lesbian, Gay, Biseksual, dan Transgender (LGBT). Dalam kajian masalah sosial, persoalan tersebut dianggap perilaku menyimpang karena tidak sesuai dengan aturan-aturan sosial ataupun norma dan nilai sosial yang berlaku. ${ }^{1}$ Akibatnya, Perilaku LGBT dikecam dan ditolak di mana-mana tanpa alasan apapun.

Dalam ilmu komunikasi, persoalan orientasi seksual ini menjadi salah satu fokus kajiannya, utamanya dalam hal hubungan relasional yang terjadi di antara dua individu atau lebih karena adanya ketertarikan satu sama lain. Termasuk

\footnotetext{
${ }^{1}$ Soerjono Soekanto, Sosiologi Suatu Pengantar, (Jakarta: PT Grafindo Persada, 1990),
} hlm. 381 . 
dalam kateori ini adalah hubungan sesama jenis yang secara konseptual tidak banyak berbeda dengan hubungan dengan lain jenis.

Secara umum, persoalan Relationship menjadi salah satu fokus studi dalam komunikasi antar pribadi yang banyak menarik perhatian banyak ilmuwan komunikasi sejak tahun 1960-an. Banyak teori yang mencoba menjelaskan dan mendefinisikan bagaimana bentuk suatu relationship dalam komunikasi antar pribadi. Hal ini juga tidak terlepas dari pengaruh latar belakang budaya dimana perspektif tersebut lahir, mengingat bahwa komunikasi adalah peristiwa sosial yang berkaitan erat dengan budaya dimana tindakan komunikasi tersebut terjadi. Perbedaan-perbedaan ini banyak mewarnai kajian komunikasi secara umum di semua level komunikasi, bukan saja dalam konteks komunikasi antar pribadi, tetapi juga dalam konteks komunikasi kelompok, organisasi, dan massa. ${ }^{2}$

Salah satu teori yang mengkaji tentang pola relationship adalah teori dialektika relasional, yang tumbuh dari ketidakpuasan akan bias-bias monologik dari penelitian komunikasi keluarga (interpersonal) tradisional, yang mana wacana-wacana tentang keterbukaan, kepastian, dan keterkaitan memiliki hak istimewa ketika wacana-wacana yang bersaing tentang non-pengungkapan, ketidakterdugaan, dan otonomi dibungkam. Teori ini telah berkembang dari fokus awalnya pada pertentangan bipolar ke artikulasinya sekarang sebagai sebuah teori dasar tentang komunikasi yang berpusat pada perjuangan wacana-wacana yang bersaing dengan sebuah metode pasangan tentang analisis wacana dan analisis contrapuntal. $^{3}$

Berangkat dari uraian tersebut di atas, peneliti menjadi tergelitik untuk mengeksplorasi lebih jauh dalam bentuk penelitian tentang pola hubungan relasional pada pasangan sejenis yang saat ini sedang menjadi wacana bersama di dalam atmosfir persoalan sosial politik di Indonesia. Guna mencapai maksimalisasi dalam penelitian ini, peneliti membatasi persoalan yang menyangkut hubungan interpersonal yang menjadi dasar lahirnya teori ini. Di antaranya: Bagaimanakah pola hubungan relasional pada pasangan sejenis ? apa makna dialektika dan dialog yang dijadikan sebagai instrumen mendasar dalam menganalisis persoalan hubungan relasional interpersonal ?

\section{TINJAUAN TEORITIS}

\section{Seksualitas, Orientasi Seksual, dan Perilaku Seksual}

Seksualitas merupakan bagaimana seseorang manusia mendapatkan pengalaman erotis dan mengekspresikan dirinya sebagai makhluk sosial, yang dalam dirinya ada kesadaran diri pribadi sebagai laki-laki atau perempuan, yang kesadaran tersebut didapat dari kapasitas yang mereka miliki atas pengalaman erotis dan tanggapan atas pengalaman tersebut. kajian mengenai seksualitas mencakup beberapa aspek, yaitu pembicaraan tentang jenis kelamin biologis (lakilaki dan perempuan), identitas gender, kemudian orientasi seksual dan perilaku seksual. Identitas gender (jenis kelamin) merupakan olahan dari konstruksi sosial,

${ }^{2}$ S. Rouli Manalu, dkk., "Teori Relational Dialectics dalam Konteks Relasi Budaya Jawa”, dalam Jurnal Ilmu Sosial, Vol. VI, No. 1, Februari 2006, hlm. 20.

${ }^{3}$ Gigin Rahmat Ginanjar, “Teori Dialektika Relasional”, (tidak dipublikasikan), hlm. 1. 
yaitu perempuan dengan femininitasnya, laki-laki dengan maskulinitasnya, dan transgender yang memiliki keduanya. Pada seseorang yang transgender, ia memiliki dua varian, yakni laki-laki keperempuanan (waria atau banci), dan perempuan kelelaki-lakian. ${ }^{4}$

Orientasi seksual merupakan kapasitas yang dimiliki oleh setiap manusia berkaitan dengan ketertarikan emosi, rasa kasih sayang, dan hubungan seksual. Ia bersifat kodrati - pemberian Tuhan yang tidak dapat diubah, karena setiap manusia tidak memiliki hak untuk memilih dilahirkan dengan orientasi seksual tertentu. ${ }^{5}$

Adapun perilaku seksual merupakan cara seseorang mengekspresikan hubungan seksualnya. Menurut Musdah Mulia, ${ }^{6}$ perilaku seksual sangat dipengaruhi oleh konstruksi sosial, tidak bersifat kodrati, dan bisa dipelajari. Cara untuk mengekspresikan hubungan seksual seperti sodomi (oral seks, anal seks, atau gaya 69) atau dalam Bahasa Arab disebut liwath. Perilaku seksual semacam inilah yang 'dianggap' menyimpang, karena seks bebas seperti itu telah menumbuh-suburkan penyakit seksual yang sampai saat ini masih belum ditemukan obatnya, yaitu AIDS, suatu sindrom kumpulan dari berbagai gejala dan infeksi sebagai akibat dari kerusakan spesifik sistem kekebalan tubuh karena inveksi virus HIV pada tubuh manusia.

Mengenai orientasi seksual yang bersifat kodrati, ada beberapa varian orientasi seksual, di antaranya: heteroseksual, homoseksual, biseksual, dan aseksual. Heteroseksual merupakan ketertarikan manusia terhadap lawan jenis; homoseksual merupakan ketertarikan manusia kepada sesame jenis kelamin, misalnya lelaki tertarik kepada lelaki (gay), perempuan tertarik kepada perempuan (lesbian). Secara sederhana, gejala homoseksualitas adalah relasi seks dengan jenis kelamin yang sama atau rasa tertarik dan mencintai jenis seks yang sama. ${ }^{7}$ Biseksual merupakan ketertarikan seksual kepada sesama jenis dan lain jenis. Artinya ia memiliki ketertarikan seksual ganda. Sedangkan aseksual merupakan ketidaktertarikan sama sekali kepada lawan jenis maupun sesama jenis.

Selain kelompok yang tersebut di atas, terdapak yang disebut waria yang merupakan kelompok transeksual atau transgender, yaitu kaum homo yang mengubah bentuk tubuhnya serupa dengan lawan jenisnya. ${ }^{8}$ Contohnya laki-laki yang mengubah dadanya dengan operasi plastik atau suntik, membuang penis beserta testisnya, dan membentuk lubang vagina. Sebagian besar transeksual adalah laki-laki yang mengenali dirinya sebagai wanita, yang timbul ketika masa kanak-kanak dan melihat alat kelamin dan penampakan kejantanannya dengan perasaan jijik.

Menurut Hesti dan Sugeng, ${ }^{9}$ ada beberaapa faktor yang menyebabkan

4 Siti Musdah Mulia, Islam dan Hak Asasi Manusia: Konsep dan Implementasi, (Yogyakarta: Naufan Pustaka, 2010), hlm. 286.

${ }^{5}$ Ibid.

${ }^{6}$ Ibid., hlm. 289.

7 Kartini Kartono, Psikologi Abnormal dan Abnormalitas Seksual, (Bandung: Mandar Maju, 1989), hal. 247.

${ }^{8}$ James Danadjaja, "Homoseksual atau Heteroseksual” dalam Srintil (ed.), Menggugat Maskulinitas dan Feminitas, (Jakarta: Kajian Perempuan Desantara, 2003), hal. 35.

${ }^{9}$ Hesti Puspitosari dan Sugeng Pujileksono, Waria dan Tekanan Sosial, Malang: UMM 
terjadinya transeksual antara lain: pertama, faktor biologis yang dipengaruhi oleh hormone seksual dan genetic seseorang; kedua, faktor psikologis dan sosial budaya, termasuk pula pola asuh lingkungan yang membesarkannya; ketiga, memiliki pengalaman yang sangat hebat dengan lawan jenis, sehingga mereka berkhayal dan memuja lawan jenis sebagai idola dan ingin menjadi seperti lawan jenis.

\section{Teori Dialektika Relasional}

Selama bertahun-tahun Leslie Baxter dan koleganya meneliti cara-cara yang kompleks, dimana seseorang yang memiliki hubungan menggunakan komunikasi untuk mengatasi kekuatan yang bertentangan secara alami yang menimpa hubungan mereka setiap saat. ${ }^{10}$ Gagasan tentang hubungan sebagai proses dialektis dan dialogis ini didasarkan pada langkah besar dalam karya Mikhail Bakhtin. Karena itu, sebelum mengkaji lebih jauh tentang teori dialektika relasional, perlu dikaji terlebih dahulu tentang teori dialogis Bakhtin yang berkontribusi langsung dalam terciptanya teori dialektika relasional.

\section{Teori Dialogis Mikhail Bakhtin}

Mikhail Bakhtin merupakan seorang filsuf dan pengajar asal Rusia yang menulis buku dan dipublikasikan pada tahun 1920-an dan 1930-an. Akan tetapi, ia tidak dikenal hingga tahun 1960-an, ketika karya-karyanya diterjemahkan dan dicetak ulang oleh para peneliti. Baru setelah masa inilah ia mulai dikenal oleh dunia atas karya-karyanya. Bahkan, saat ini gagasan-gagasannya dikenal dalam seluruh ilmu yang bergerak dalam bidang kemanusiaan dan ilmu pengetahuan sosial. $^{11}$

Dalam teori dialogis, Bakhtin memulainya dengan gagasan tentang realitas sehari-hari - makan, minum, tidur, berjalan, dan berbicara. Bakhtin melihat dunia sehari-hari ini sebagai titik awal dari segala macam perubahan yang terjadi sangat lambat yang tidak dapat diamati, hingga terjadi tindakan berupa keputusankeputusan penting yang dibuat. ${ }^{12}$ Keputusan yang terakumulasi dari hal-hal yang kecil dan sepele, seperti apa yang harus dipakai, harus pergi kemana, ataupun harus makan apa, menjadi persoalan besar - norma-norma, nilai, standar, dan sistem sosial.

Dengan menggunakan metafora dari fisika, Bakhtin mengenali dua jenis kekuatan umum yang mempengaruhi kehidupan sehari-hari, yakni sentripetal dan sentrifugal. ${ }^{13}$ Kekuatan sentripetal (centripetal force), yaitu kekuatan yang bergerak menuju ke pusat, dan kekuatan sentrifugal (centrifugal force), yaitu kekuatan yang bergerak menjauh dari pusat. Kedua kekuatan itu bisa dianalogikan

Press,2005. hal. v.

${ }^{10}$ Leslie Baxter, "Relationships as Dialogues", dalam Personal Relationships, (2004), hlm. 1-22.

${ }^{11}$ Stephen W. Littlejohn dan Karen A. Foss, Theories of Human Communication, terj. M. Yusuf Hamdan, (Jakarta: Salemba Humanika, 2008), hlm. 298.

12 Gary Saul Morson dan Caryl Emerson, Mikhail Bakhtin: Creation of Prosaics, (Stanford, CA: Stanford University Press, 1990), hlm. 23.

${ }^{13}$ Ibid., hlm. 30. 
sebagai berikut: bahwa kekuatan sentripetal seperti gravitasi yang menarik objek menuju pusat gravitasi, sedangkan kekuatan sentrifugal seperti putaran yang menarik objek menjauh dari pusat gravitasi. Ketika sebuah roket meluncur ke angkasa, gravitasi ingin menariknya kembali ke bumi, akan tetapi pada titik tertentu, kekuatan di luar gravitasi bumi menariknya menjauh dari bumi. ${ }^{14}$

Kehidupan sosial tepat seperti ini. Ketika sebuah presentasi sudah dipersiapkan dengan begitu matang dan ideal, ternyata dalam perjalanan menuju lokasi presentasi ada kendala teknis, ban sepeda bocor yang menyebabkan presentasi menjadi terhambat. Berdasarkan kejadian tersebut, bisa disimpulkan bahwa di satu sisi, ada beberapa kekuatan yang mendukung perintah, sedangkan di sisi yang lain, dengan sengaja atau tidak, ada kekuatan-kekuatan lain yang berusaha menghambat apa yang sudah direncanakan dengan baik.

Dalam konteks kehidupan, teori dialogis Bakhtin ini berusaha merepresentasikan realitas bahwa diri kita dan orang lain bersifat konstitutif terhadap penciptaan jati diri satu sama lain. Ada persamaan gagasan antara pemikiran Levinas dan Bakhtin yang menyoroti pentingnya kehadiran orang lain dalam mendefinisikan dan mengkonstruksikan self (diri). Akan tetapi, ada perbedaan yang mendasar di antara gagasan kedua tokoh tersebut. Bagi Levinas, hubungan antara self dengan alteritas (other) sebagai hubungan yang tidak simetris. Dalam hal ini, self berarti menjadi seseorang bagi orang lain. Subyek menjadi seseorang ketika dia mengambil tanggung jawab atas kehadiran orang lain. Tanggung jawab disini cenderung bersifat sepihak, yaitu dari subyek (self) kepada orang lain, sementara orang lain tidak dituntut untuk memiliki tanggung jawab atas kehadiran kita. Sementara bagi Bakhtin, melalui konsep dialogisnya, other merupakan bagian yang tidak terpisahkan dalam membangun kesadaran akan self. Relasi dialogis antara self dan other yang setara itulah yang membangun kesadaran akan diri pada kedua belah pihak. Melalui penjelasan ini, Bakhtin menyebutkan self dan other bukanlah entitas yang berdiri sendiri, melainkan bersifat co-being (kemenjadian) bagi satu sama lain. Co-being ini menimbulkan konsekuensi munculnya answerability atau saling merespon kehadiran satu sama lain. ${ }^{15}$

Other dalam konsep dialogis Bakhtin dibutuhkan karena self tidak pernah mampu melihat dirinya sendiri secara utuh. Keutuhan diri bisa terbentuk apabila ada orang lain yang ikut menunjukkan atau membantu mengungkapkan keutuhan diri. Oleh sebab itulah keberadaan setiap individu hanya menjadi co-being, sebab being baru muncul melalui relasi antara self dan other yang kemudian melakukan proses penciptaan (penulisan) self bersama. ${ }^{16}$

\section{Teori Baxter tentang Hubungan (Relasional)}

Selama bertahun-tahun Baxter telah melihat karya dialogis Bakhtin sebagai sebuah cara yang lebih baik untuk memahami perubahan dan aliran hubungan. Dengan menggabungkan banyak konsep Bakhtin, Baxter menyebut

\footnotetext{
${ }^{14}$ Stephen W. Littlejohn dan Karen A., ibid., hlm. 299.

15 Adi Wibowo, "Intisari Pemikiran Dialogisme Bakhtin", dalam Citizen Magazine, Bandung, 6 Februari 2010, hlm. 34.

${ }^{16}$ Ibid.
} 
teorinya sebagai teori dialogis tentang hubungan. Dengan kata lain, hubungan diartikan melalui sebuah dialog antara banyak suara. Pada saat yang sama, Baxter juga menggambarkan teorinya sebagai dialektis, yang berarti bahwa hubungan merupakan sebuah tempat yang menangani pertentangan. ${ }^{17}$

Dalam konteks ini, dialektis mengacu kepada sebuah tekanan antara kekuatan-kekuatan yang berlawanan dalam sebuah sistem. Dalam kehidupan, sering terjadi "suara-suara" yang memaksa dalam pengambilan keputusan. Contohnya, dalam diri seseorang, terdapat sisi kemanusiaan yang ingin diaktualisasikan dalam bentuk membantu fakir miskin dan anak-anak terlantar. Namun untuk merealisasikan keinginannya tersebut, dibutuhkan dana (materi) yang banyak. Artinya, untuk bisa merealisasikannya, seseorang dituntut untuk bisa sukses secara materi. Dalam contoh ini, terdapat dua hal yang bertolak belakang, di satu sisi ada hasrat untuk mengumpulkan uang sebanyak-banyaknya sebagai bentuk indikasi kesuksesan, tetapi di sisi lain juga ada hasrat untuk mengeluarkan uang banyak sebagai bentuk aktualisasi diri dari rasa kemanusiaan.

Sedangkan dialog, secara umum dimaknai sebagai suara-suara berbeda yang menyatu dalam sebuah percakapan. Dalam hal ini, Baxter memandang dialog sebagai percakapan yang mendefinisikan ulang hubungan ketika hubungan muncul dalam situasi yang sebenarnya. Karena itu, ada beberapa makna penting dialog, di antaranya ${ }^{18}$ :

1. Hubungan dihasilkan melalui dialog

2. Dialog menghasilkan sebuah kesempatan untuk mencapai sebuah persatuan dalam perbedaan

3. Stabilitas-pertentangan atau tekanan antara sesuatu yang dapat diduga dan konsisten melawan spontanitas dan perbedaan

Carol Werner dan Leslie Baxter menulis lima kualitas yang berubah ketika suatu hubungan menjadi berkembang ${ }^{19}$ :

1. Amplitudo - kekuatan perasaan, perilaku, atau keduanya. Misalnya, pada titik-titik tertentu dalam sebuah hubungan, seseorang mungkin sangat aktif dan sensitif terhadap sesuatu yang terjadi, namun di lain waktu lebih santai dan tenang.

2. Kepentingan - fokus pada masa lalu, sekarang, atau masa depan.

3. Skala - seberapa lama pola-pola tersebut bertahan: cepat berubah ataukah cukup lama bertahan.

4. Rangkaian - susunan kejadian dalam hubungan. Ketika terjadi perubahan dalam suatu hubungan, banyak hal yang bisa dilakukan, akan tetapi tidak semuanya diatur dalam waktu yang sama. Terkadang stabil dan bertahan lama, tetapi terkadang hanya seumur jagung.

${ }^{17}$ Baxter, "Relationships as Dialogues"; Baxter dan Braithwaite, "Social Dialectics: The Contradictions of Relating”. Lihat juga Stephen W. Littlejohn dan Karen A., ibid., hlm. 302.

${ }^{18}$ Ibid., hlm. 303-305.

19 Carol M. Werner dan Leslie A. Baxter, "Temporal Qualities of Relationships: Organismic, Transactional, and Dialectical Views", dalam Mark L. Knapp dan Rerard R. Miller (ed.), Handbook of Interpersonal Communication, (Thousand Oaks, CA: Sage, 1994), hlm. 323379. 
5. Langkah/Irama - kecepatan kejadian dalam hubungan dan jarak antar kejadian. Selama periode tertentu dalam sebuah hubungan, banyak kejadian yang mungkin terjadi dengan cepat ataupun lambat. Hubungan digambarkan oleh kombinasi dari beberapa variabel. Menelusuri perkembangan berarti memperhatikan cara-cara dimana profil selalu berubah.

\section{Konsep Dasar Teori Dialektika Relasional}

Teori Dialektika Relasional merupakan suatu teori yang menjelaskan tentang relationship (hubungan) dalam studi komunikasi, yang lahir dari perspektif Barat. Teori ini mencoba untuk menjelaskan bagaimana dinamika dan hambatan-hambatan yang terjadi dalam suatu hubungan, yang dalam hal ini hubungan percintaan (romantic relationship) dan juga hubungan rumah tangga atau suami-isteri (married couples). Teori ini merupakan hasil penelitian dari Leslie Baxter dan Barbara Montgomery. ${ }^{20}$ Studi tersebut mereka lakukan dengan mewawancarai beberapa orang dengan latar belakang budaya Barat (Amerika). Studi ini dilakukan di akhir tahun 1980-an sampai awal tahun 1990-an. Dalam penelitian tersebut, ditemukan beberapa prinsip penting yang menjadi ide utama dalam teori tersebut ${ }^{21}$ :

\section{Asumsi utama}

Apapun bentuk suatu keakraban atau keintiman dalam suatu hubungan, dimana hubungan tersebut merupakan suatu bentuk jalinan yang tidak beraturan dari suatu proses yang tidak stabil (selalu berubah). Asumsi ini diperjelas dengan adanya premis: relasi diorganisasikan dalam suatu interaksi yang dinamis antara kecenderungan-kecenderungan yang saling berlawanan yang terdapat dalam suatu hubungan. Dengan kata lain, teori ini menyatakan bahwa kontradiksi merupakan konsep utama dalam dialektika suatu hubungan.

2. Pasangan yang terlibat dalam hubungan berusaha dan berjuang untuk memberikan respon pada situasi konflik tarik ulur terhadap perasaan mereka di dalam suatu relasi.

Perspektif dialektis teori ini menekankan bahwa pasangan secara konstan berusaha untuk menyeimbangkan tekanan-tekanan yang saling berlawanan yang terdapat di dalam hubungan. Baxter dan Montgomery mengemukakan tiga kekuataan atau tekanan yang saling berlawanan di dalam hubungan, yang disebut dengan internal dialectic (dialektika internal) ${ }^{22}$, yaitu:

a. Connectedness and Separatedness (Penghubungan dan Pemisahan)

b. Certainty and Uncertainty (Kepastian dan Ketidakpastian)

c. Openness and Closedness (Keterbukaan dan Ketertutupan)

Tradisi Barat yang memiliki kecenderungan berpandangan individualism (lebih bersifat individu), sangat nyata pengaruhnya dalam Teori Dialektika Relasional ini, dimana orang-orang yang terlibat dalam tindakan komunikasi

\footnotetext{
${ }^{20}$ Baxter, ibid.

${ }^{21}$ Ibid., hlm. 304.

${ }^{22}$ Ibid.
} 
dipandang memiliki tujuan yang ingin dicapai, demikian juga halnya di dalam relasinya dengan pasangannya. Selain itu, relationship dipandang hanya sebagai hubungan yang terjalin antara dua orang. Oleh karena itu, relasi tidak memperhitungkan status dan peran individu dalam konteks yang lebih luas, maka akan terlihat jika kedua pihak yang terlibat dalam suatu relationship memiliki posisi yang sama. Atau dengan kata lain, laki-laki dan perempuan memiliki posisi tawar yang sama dalam suatu relasi. Karena itu, adanya kontradiksi dalam hubungan bisa dilihat sebagai sesuatu yang seimbang antara kedua belah pihak. ${ }^{23}$

\section{Asumsi dalam Teori Dialektika Relasional}

Teori Dialektika Relasional didasarkan pada empat asumsi pokok yang merefleksikan argumennya mengenai hidup berhubungan ${ }^{24}$ :

1. Hubungan tidak bersifat linear

2. Hidup berhubungan ditandai dengan adanya perubahan

3. Kontradiksi merupakan fakta fundamental dalam hidup berhubungan

4. Komunikasi sangat penting dalam mengelola dan menegosiasikan kontradiksi-kontradiksi dalam hubungan

\section{Elemen-elemen Dasar dalam Perspektif Dialektika}

\section{Totalitas}

Ada beberapa elemen dasar dalam perspektif dialektika, di antaranya:

Totalitas berarti menyatakan bahwa orang-orang di dalam suatu hubungan saling tergantung. Ini berarti ketika sesuatu terjadi pada salah satu anggota, maka anggota yang lain juga akan terpengaruh. Misalnya, ketika sang suami mendapatkan promosi kenaikan jabatan yang mengharuskan dirinya sering bepergian daripada sebelumnya, maka sang isteri juga harus menghadapi saat-saat sang suami jarang di rumah. Ia mungkin akan berkompensasi dengan cara berteman dengan banyak orang di luar hubungan mereka berdua, dan ini juga sedikit banyak akan berpengaruh terhadap sang suami ketika suatu saat berada di rumah, karena ia harus bertemu dengan teman-teman baru sang isteri.

\section{Kontradiksi}

Kontradiksi merupakan ciri utama dalam perspektif dialektika. Adapun dialektika merupakan hasil dari oposisi-oposisi.

\section{Pergerakan}

Pergerakan disini merujuk pada sifat berproses dari hubungan dan perubahan yang terjadi pada hubungan itu seiring dengan berjalannya waktu. Misalnya, bandingkan kualitas hubungan ketika masih proses pacaran dengan setelah menikah. Pasti ada pergeseran yang cukup berarti.

\section{Praksis}

Praksis berarti manusia adalah pembuat keputusan. Meskipun seseorang tidak sepenuhnya memiliki pilihan bebas dalam setiap kesempatan

${ }^{23}$ S. Rouli Manalu, dkk., ibid., hlm. 22.

${ }^{24}$ Richard West dan Lynn H. Turner, Introducing Communication Theory: Analysis and Application, terj. Brian Marswendy, (Jakarta: Mc Graw Hill Education, 2014), hlm. 236. 
dan dibatasi oleh pilihan-pilihan sebelumnya, pilihan-pilihan orang lain, serta kondisi sosial-budaya yang ada, tetapi setiap orang tetap merupakan pengambil keputusan yang sadar sepenuhnya dan aktif. Misalnya, ketika Krisdayanti memutuskan diri untuk memilih sebagai pendamping hidup bagi Raul Lemos, maka ia mau tidak mau harus menyesuaikan diri dengan kehidupan Raul Lemos di Timur Leste yang jauh dari suasana glamoritas keartisan ibukota Jakarta. Bukan hanya itu saja, pilihan tersebut akan membatasi pilihan-pilihan yang lain yang mungkin akan dibuatnya. Ia harus bergaul dengan orang tua dan saudara-saudara Raul Lemos ketika berlibur bersama. Meskipun secara pribadi ia mungkin kurang suka memilih untuk bergaul dengan mereka, akan tetapi karena ia mencintai Raul Lemos, maka ia harus menghabiskan waktu bersama mereka.

\section{Dialektika Kontekstual}

Para peneliti membahas adanya dialektika lain yang mempengaruhi hidup berhubungan. William Rawlins menyebut hal ini sebagai dialektika kontekstual, yang berarti bahwa dialektika ini muncul dari tempat hubungan tersebut di dalam budaya. ${ }^{25}$ Dialektika kontekstual dibagi menjadi dua bagian, yaitu ${ }^{26}$ :

\section{Dialektika publik dan privat (public and private dialectic)}

Rawlins membahas fakta bahwa dalam wilayah publik, persahabatan menempati posisi yang marginal. Lilian Rubin juga mengamati hal yang sama dan menemukan bahwa harapan publik cenderung lebih mendukung hubungan bersaudara dibandingkan persahabatan, bahkan saat seseorang lebih menghargai persahabatannya daripada keluarganya. Rubin berargumentasi bahwa orang cenderung menempatkan komitmen kepada teman sebagai prioritas yang lebih rendah dibandingkan dengan komitmen kepada anggota keluarga. Akan tetapi, kehidupan hubungan yang privat terkait erat dengan kehidupan publik. Contohnya seorang politikus hidup dalam wilayah publik, tetapi juga memiliki kehidupan privat.

\section{Dialektika yang nyata dan ideal (real and ideal dialectic)}

Dialektika ini menunjukkan adanya kontradiksi akan semua harapan yang dimiliki seseorang mengenai hubungannya dengan kenyataan yang sedang dijalani. Secara umum, harapan mengenai hubungan biasanya memiliki standar yang tinggi dan ideal. Persahabatan dipandang sebagai tempat munculnya kasih sayang, kesetiaan, dan kepercayaan. Persahabatan dipandang sebagai tempat berlindung di dalam dunia yang penuh kesulitan. Orang-orang yang dicintai dipercaya akan memberikan kasih sayang dan dukungan tanpa batas dan pamrih. Namun, kita tahu bahwa hubungan interpersonal tidak selalu menyenangkan dan memiliki sisi-sisi gelap yang bertolak belakang dengan pemikiran ideal ini. Teori dialektika berusaha menjelaskan bagaimana orang hidup dan bagaimana mengelola kontradiksikontradiksi ini.

\footnotetext{
25 Richard West dan Lynn H. Turner, ibid., hlm. 241.

${ }^{26}$ Ibid., hlm. 241-242.
} 


\section{Respon terhadap Dialektika}

Meskipun ketegangan dialektika merupakan sesuatu hal yang berlangsung terus menerus, namun setiap orang selalu melakukan usaha untuk mengelola ketegangan tersebut. Baxter mengidentifikasi ada empat strategi yang bisa dilakukan dalam menghadapi ketegangan-ketegangan tersebut ${ }^{27}$ :

\section{Pergantian siklus}

Strategi ini diambil ketika terjadi dua hal yang berlawanan dalam satu waktu. Tindakan yang bisa dilakukan yaitu dengan melakukan pergantian secara teratur.

\section{Segmentasi}

Segmentasi artinya memisahkan antara persoalan pekerjaan dengan persoalan keluarga. misalnya, seorang suami dan isteri yang bekerjasama dalam bisnis keluarga mungkin akan menekankan sifat profesionalitas dalam urusan bisnis dan keluarga sebagai dua hal yang berbeda.

\section{Seleksi}

Seleksi ini merujuk kepada pembuatan keputusan antara dua hal yang berlawanan.

\section{Integrasi}

Tindakan integrasi merupakan suatu sintesis dari dua hal yang saling berlawanan. Dalam hal ini, ada tiga bentuk integrasi, yaitu:

\section{a. Menetralisasi}

Tindakan menetralisasi membutuhkan adanya kompromi antara dua kutub. Seseorang yang memilih strategi ini akan mencoba menemukan medium yang membuat mereka bahagia di antara dua hal yang berlawanan.

\section{b. Membingkai ulang}

Tindakan ini merujuk kepada transformasi dialektika yang ada dengan cara tertentu, sehingga dialektika itu seperti tidak memiliki oposisi. Julia Wood dan koleganya mendiskusikan bagaimana pasanganpasangan membingkai ulang dengan cara mendefinisikan kembali keterikatan sebagai sesuatu hal yang mencakup perbedaan-perbedaan yang ada. Karena itu, dialektika antara otonomi dengan keterikatan dianggap kesatuan daripada sebagai oposisi.

c. Mendiskualifikasi polaritas

Mendiskualifikasi polaritas artinya menetralkan dialektika dengan memberikan pengecualian pada beberapa isu dari pola umum. Sebuah keluarga mungkin sangat terbuka dalam komunikasi mereka secara umum tetapi memiliki beberapa topik tabu yang tidak akan didiskusikan sama sekali, seperti masalah seks dan keuangan.

\section{METODE PENELITIAN}

Dalam penelitian ini, pendekatan yang digunakan adalah pendekatan yang menggunakan pola penelitian kualitatif, yaitu suatu penelitian ilmiah yang

${ }^{27}$ Ibid., hlm. 244-246. 
bertujuan untuk memahami suatu fenomena dalam konteks sosial secara alamiah dengan mengedepankan proses interaksi komunikasi yang mendalam antara peneliti dengan fenomena yang diteliti. ${ }^{28}$

Adapun alasan menggunakan pendekatan dengan pola penelitian kualitatif adalah karena topik yang diangkat benar-benar untuk dieksplorasi secara mendalam, juga untuk mempelajari subjek dalam latar alamiah, yaitu lingkungan alamiah, normal, dan tanpa adanya intervensi atau perlakuan yang diberikan oleh peneliti. Situasi yang diteliti benar-benar natural dan apa adanya. ${ }^{29}$

Adapun jenis penelitan yang digunakan dalam penelitian ini adalah jenis penelitian analisis deskriptif, yaitu penelitian yang dilakukan dengan cara peneliti menganalisa data yang dikumpulkan berupa kata-kata, gambar, dan bukan angkaangka. Data tersebut mungkin berasal dari naskah wawancara, catatan lapanggan, foto, videotape, dokumen pribadi, catatan atau memo, dan dokumen resmi lainnya. ${ }^{30}$

Dalam penelitian ini, teknik cuplikan cenderung menggunakan teknik cuplikan yang bersifat selektif dengan menggunakan pertimbangan berdasarkan konsep teoritis yang digunakan, keingintahuan pribadi peneliti, karakteristik empirisnya, dan sebagainya, sehingga cuplikan yang akan digunakan dalam penelitian ini bersifat purposive sampling, karena cuplikan ini lebih cenderung sebagai internal sampling, yakni memberikan kesempatan bahwa keputusan bisa diambil begitu peneliti mempunyai suatu pikiran umum yang muncul mengenai apa yang sedang dipelajari, dengan siapa berbicara, kapan perlu melakukan observasi yang tepat (time sampling), dan juga berapa jumlah serta macam dokumen yang perlu ditelaah. Dalam hal ini peneliti memilih informan meliputi:

$\begin{array}{ll}\text { 1. Nama } & : \text { Abi (nama samaran) } \\ \text { Alamat } & : \text { Brangkal - Mojokerto } \\ \text { Usia } & : \text { :37 tahun } \\ \text { Pekerjaan } & : \text { swasta } \\ \text { 2. Nama } & : \text { Aldo (nama samaran) } \\ \text { Alamat } & : \text { Kota Mojokerto } \\ \text { Usia } & : \text { :50 tahun } \\ \text { Pekerjaan } & : \text { salon dan perias pengantin } \\ \text { 3. Nama } & : \text { Ricky (nama samaran) } \\ \text { Alamat } & : \text { Sidoarjo } \\ \text { Usia } & : 28 \text { tahun } \\ \text { Pekerjaan } & : \text { salon }\end{array}$

\section{PEMBAHASAN}

1. Hubungan tidak bersifat linear

\footnotetext{
${ }^{28}$ Ibid., hlm. 9.

${ }^{29}$ Ibid., hlm. 16.

${ }^{30}$ Lexy J. Moeloeng, Metode Penelitian Kualitatif, (Bandung: Remaja Rosdakarya,
} 2010), hlm. 11. 
Hubungan tidak terdiri atas bagian-bagian yang bersifat linear. Sebaliknya, hubungan terdiri atas fluktuasi yang terjadi antara keinginankeinginan yang kontradiktif. Dalam hal ini, ketiga responden penelitian berpendapat bahwa pemikiran mereka dengan pasangan mereka tidak selalu searah, karena selalu ada kontradiksi-kontradiksi yang terjadi di antara mereka, meskipun intensitasnya agak jarang. Namun, mereka bertiga menyadari bahwa perbedaan itu sesuatu yang tidak mungkin untuk dihindari, karena itu menurut mereka, hal yang terpenting dalam menjalin hubungan mereka adalah jangan sampai menjadikan perbedaan tersebut sebagai penyebab utama keretakan hubungan mereka. Tidak mungkin dua individu yang berbeda akan selalu mempunyai pemikiran yang searah, oleh sebab itu kontradiksi yang ada tidak terlalu mereka permasalahkan.

2. Hidup berhubungan ditandai dengan adanya perubahan, meskipun perubahan yang terjadi tidak selalu bersifat linear, akan tetapi proses atau perubahan suatu hubungan tersebut merujuk pada pergerakan kuantitatif dan kualitatif sejalan dengan waktu dan kontraksi-kontraksi yang terjadi di seputar hubungan tersebut. Dalam hal perubahan, ketiga responden juga berpendapat bahwa perubahan yang terjadi dalam hubungan mereka memang ada. Apa yang mereka rasakan pada awal-awal hubungan terbilang sangat romantis dan ideal sebagai sepasang kekasih yang sedang fall in love dengan merasakan seakan-akan dunia hanya milik mereka berdua, namun dengan berjalannya waktu, adanya persoalan-persoalan yang menimpa hubungan mereka pada akhirnya mengurangi kedekatan mereka, meskipun tidak sampai putus. Yang terpenting hubungan di antara mereka tetap terjalin dengan baik. Bahkan, responden kedua mengatakan bahwa hubungan mereka yang semula didasarkan pada dorongan nafsu biologis, namun seiring dengan berjalannya waktu, rasa cinta kasih yang mereka tunjukkan berubah menjadi rasa sayang. Seakan-akan hubungan kedekatan mereka lebih dari saudara. Rasa sayang inilah yang menjadikan hubungan mereka menjadi langgeng, meskipun dalam hubungan tersebut muncul banyak persoalan.

3. Kontradiksi merupakan fakta fundamental dalam hidup berhubungan, karena kontradiksi atau ketegangan yang terjadi antara dua hal yang berlawanan tersebut tidak pernah hilang dan tidak akan pernah berhenti. Setiap orang mengelola ketegangan dan oposisi ini dengan cara yang berbeda-beda, tetapi kedua hal ini selalu ada dalam hidup berhubungan. Tarikan dan dorongan yang direpresentasikan oleh dialektika mengkonstruksi hidup berhubungan. Dalam hal ini, tugas komunikasi adalah mengelola ketegangan-ketegangan ini. Menurut ketiga responden penelitian, kontradiksi atau ketegangan yang mereka rasakan dalam menjalin hubungan kasih sayang selalu saja muncul, baik yang berasal dari dalam, maupun yang berasal dari luar. Kontradiksi tersebut biasanya berkisar pada persoalan-persoalan yang sepele seperti keputusan mau belanja kemana, pergi kemana, ataupun masalah prinsipprinsip hidup masing-masing yang terkadang tidak bisa disamakan. Adapun Solusi yang mereka lakukan dalam mengelola ketegangan tersebut berbedabeda, responden pertama mengelola kontradiksi tersebut dengan mengkomunikasikan apa yang menjadi unek-unek dalam hatinya, supaya 
pasangannya menjadi lebih mengerti dan bisa memahaminya; responden kedua memberikan solusi ketika terjadi kontradiksi dengan cara melakukan refleksi masing-masing atas kesalahan yang mereka lakukan supaya persoalan tersebut bisa secepatnya diselesaikan; adapun responden ketiga berpendapat bahwa solusi yang mereka ambil adalah dengan melakukan aktivitas yang menyenangkan, seperti berbelanja ataupun kuliner untuk menurunkan ketegangan yang terjadi. Adapun negosiasi yang mereka gunakan adalah dengan cara keputusan akan disesuaikan dengan keinginan pasangan secara bergantian.

4. Komunikasi sangat penting dalam mengelola dan menegosiasikan kontradiksi-kontradiksi dalam hubungan. Praktek-praktek komunikasi mengorganisasikan tiga dialektika utama: otonomi dan keterikatan, keterbukaan dan perlindungan, serta sesuatu yang baru dan sesuatu yang bisa diprediksi. Dalam hal praktek komunikasi, ketiga responden mempunyai pola yang berbeda. Responden pertama berpendapat bahwa dalam hubungan mereka, ada hak otonomi yang dimiliki oleh masing-masing anggota pasangan untu menentukan sikap sesuai dengan apa yang diinginkan, sebatas hal itu tidak membahayakan hubungan mereka, misalnya selingkuh, namun di sisi lain, hubungan mereka menjadi terikat satu-sama lain, artinya hubungan tersebut telah membatasi hubungan mereka dengan orang lain. Dalam hal keterbukaan dan privasi, mereka berdua tidak selalu terbuka, karena terkadang mereka juga menyembunyikan kebenaran demi untuk keutuhan hubungan mereka. Masalah privasi juga sangat dijaga, dengan cara tidak saling mencampuri urusan pribadi masing-masing. Kejutan-kejutan yang dilakukan oleh pasangan juga terkadang dilakukan untuk me-refresh hubungan mereka. Perasaan mereka ketika mendapatkan kejutan tentunya senang dan berbunga-bunga, sehingga menyebabkan hubungan mereka menjadi lebih dekat dari sebelumnya. Adapun responden kedua juga selalu memberikan hak otonomi kepada pasangannya untuk bertindak sesuai dengan karakteristik dirinya dalam hal-hal yang tidak membahayakan hubungan. Meskipun keterikatan yang senantiasa mereka bangun tetap harus ditegakkan. Dalam hal keterbukan dan privasi, responden kedua mempunyai persamaan dengan responden pertama. Mengenai kejutan yang dilakukan oleh pasangan, responden kedua mengatakan tidak pernah terjadi dalam hubungan mereka. Sementara itu, pada responden ketiga, rasa ketergantungan satu sama lain sangat tinggi, sehingga menjadikan mereka menjadi kurang bisa otonom. Kejutan-kejutan yang diberikan oleh pasangan juga jarang terjadi dalam hubungan mereka, meskipun adanya kejutan tersebut bisa menjadikan suasana menjadi lebih hangat dan akrab.

5. Dialektika publik dan privat. Dalam kehidupan pasangan, dialektika antara persoalan publik dan privat kerap terjadi, namun ketiga responden tidak terlalu mempersoalkan hal tersebut. Bahkan mereka mampu untuk menghormati peroalan-persoalan publik dan privat pasangan mereka masingmasing.

6. Dialektika yang nyata dan ideal. Dialektika ini menunjukkan adanya kontradiksi akan semua harapan yang dimiliki seseorang mengenai hubungannya dengan kenyataan yang sedang dijalani. Secara umum, harapan 
mengenai hubungan biasanya memiliki standar yang tinggi dan ideal. Persahabatan dipandang sebagai tempat munculnya kasih sayang, kesetiaan, dan kepercayaan. Persahabatan dipandang sebagai tempat berlindung di dalam dunia yang penuh kesulitan. Orang-orang yang dicintai dipercaya akan memberikan kasih sayang dan dukungan tanpa batas dan pamrih. Namun, kita tahu bahwa hubungan interpersonal tidak selalu menyenangkan dan memiliki sisi-sisi gelap yang bertolak belakang dengan pemikiran ideal ini. Teori dialektika berusaha menjelaskan bagaimana orang hidup dan bagaimana mengelola kontradiksi-kontradiksi ini. Dalam hal idealitas hubungan, ketiga responden seakan-akan bersepakat bahwa hubungan sejenis bukanlah hubungan yang langgeng, karena sifatnya sementara saja. Karena itu ketiga responden ini sepakat bahwa dalam menjalin hubungan, mereka menggunakan prinsip mengalir saja tanpa adanya target-target tertentu, apalagi harus menjalin hubungan yang ideal. Sungguh hal ini berada di luar ekspektasi mereka.

\section{SIMPULAN}

Dialektis mengacu kepada sebuah tekanan antara kekuatan-kekuatan yang berlawanan dalam sebuah sistem. Dalam kehidupan, sering terjadi "suara-suara" yang memaksa dalam pengambilan keputusan. Sedangkan dialog, secara umum dimaknai sebagai suara-suara berbeda yang menyatu dalam sebuah percakapan. Dalam hal ini, Baxter memandang dialog sebagai percakapan yang mendefinisikan ulang hubungan ketika hubungan muncul dalam situasi yang sebenarnya.

Teori Dialektika Relasional didasarkan pada empat asumsi pokok yang merefleksikan argumennya mengenai hidup berhubungan:

1. Hubungan tidak bersifat linear. Dalam hal ini, pemikiran mereka dengan pasangan tidak selalu linear, karena setiap individu selalu mempunyai pemikiran yang berbeda dengan individu lainnya, meskipun mereka adalah sepasang kekasih.

2. Hidup berhubungan ditandai dengan adanya perubahan. Bagi mereka, perubahan tidak mungkin untuk dipungkiri, karena perubahan adalah bagian dari kehidupan. Karena itu perubahan yang mereka alami dalam hubungan mereka dianggap sesuatu yang wajar terjadi. Meskipun intensitas perubahan tersebut menunjukkan grafik penurunan, namun hal itu tidak menyebabkan hubungan mereka harus berakhir.

3. Kontradiksi merupakan fakta fundamental dalam hidup berhubungan. Dalam hal hubungan, kontradiksi juga tidak bisa dihindari, namun harus selalu ada solusi bagi mereka dalam mengakomodir kontradiksi tersebut supaya tidak menimbulkan masalah yang bisa membahayakan hubungan mereka.

Komunikasi sangat penting dalam mengelola dan menegosiasikan kontradiksi-kontradiksi dalam hubungan. Komunikasi inilah yang menjadi kunci utama dalam menjaga kelanggengan hubungan mereka. Karena itu, mereka selalu menjalin komunikasi supaya tidak terjadi kesalahpahaman di antara mereka. Komunikasi juga sebagai jembatan dalam menyelesaikan persoalan-persoalan 
yang ada secara tuntas.

\section{DAFTAR PUSTAKA}

Baxter, Leslie. 2004. "Relationships as Dialogues", Personal Relationships.

Baxter, "Relationships as Dialogues"; Baxter dan Braithwaite, "Social Dialectics:

The Contradictions of Relating".

Danadjaja, James. 2003. "Homoseksual atau Heteroseksual”, Srintil (ed.),

Menggugat Maskulinitas dan Feminitas. (Jakarta: Kajian Perempuan Desantara).

Hadi, Sutrisno. 2001. Metodologi Research, Jilid I. (Yogyakarta: Andi Offset).

Herdiansyah, Haris. 2010. Metodologi Penelitian Kualitatif, (Jakarta: Salemba Humanika).

Kartono, Kartini. 1989. Psikologi Abnormal dan Abnormalitas Seksual. (Bandung: Mandar Maju).

Littlejohn, Stephen W. dan Karen A. Foss. 2008. Theories of Human Communication, terj. M. Yusuf Hamdan. (Jakarta: Salemba Humanika).

Mahmud. 2016. Metodologi Penelitian. (Mojokerto: Thoriq al-Fikri).

Manalu, S. Rouli, dkk., "Teori Relational Dialectics dalam Konteks Relasi Budaya Jawa", Jurnal Ilmu Sosial. Vol. VI, No. 1, Februari 2006.

Moeloeng, Lexy J. 2010. Metode Penelitian Kualitatif. (Bandung: Remaja Rosdakarya).

Morson, Gary Saul dan Caryl Emerson. 1990. Mikhail Bakhtin: Creation of Prosaics. (Stanford, CA: Stanford University Press).

Mulia, Siti Musdah. 2010. Islam dan Hak Asasi Manusia: Konsep dan Implementasi. (Yogyakarta: Naufan Pustaka).

Nasution, S. 1964. Azas-azas Kurikulum. (Bandung: Penerbit Terate).

Puspitosari, Hesti dan Sugeng Pujileksono. 2005. Waria dan Tekanan Sosial. (Malang: UMM Press).

Soekanto, Soerjono. 1990. Sosiologi Suatu Pengantar, (Jakarta: PT Grafindo Persada).

Surahman, Winarno. 1998. Pengantar Penelitian Ilmiah. (Bandung: Tarsitio). 
Werner, Carol M. dan Leslie A. Baxter. 1994. “Temporal Qualities of Relationships: Organismic, Transactional, and Dialectical Views", Mark L. Knapp dan Rerard R. Miller (ed.), Handbook of Interpersonal Communication. (Thousand Oaks, CA: Sage).

West, Richard dan Lynn H. Turner. 2014. Introducing Communication Theory: Analysis and Application, terj. Brian Marswendy. (Jakarta: Mc Graw Hill Education).

Wibowo, Adi. "Intisari Pemikiran Dialogisme Bakhtin", Citizen Magazine. Bandung, 6 Februari 2010 